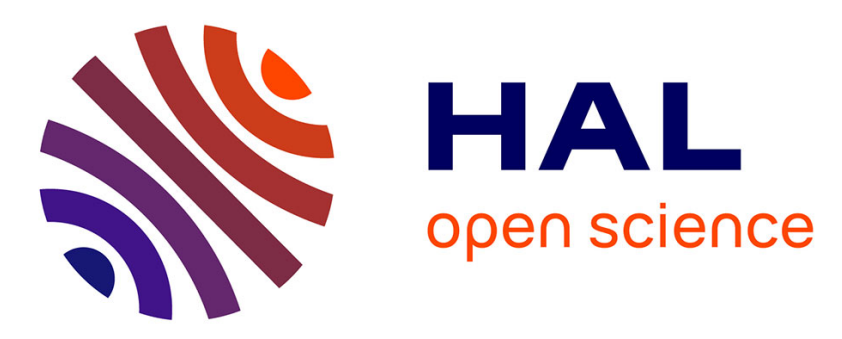

\title{
How the structure, nutritional and sensory attributes of pasta made from legume flour is affected by the proportion of legume protein
}

Karima Laleg, Cécile Barron, Sylvie Cordelle, Pascal Schlich, Stéphane

Walrand, Valérie Micard

\section{To cite this version:}

Karima Laleg, Cécile Barron, Sylvie Cordelle, Pascal Schlich, Stéphane Walrand, et al.. How the structure, nutritional and sensory attributes of pasta made from legume flour is affected by the proportion of legume protein. LWT - Food Science and Technology, 2017, 79, pp.471-478. 10.1016/j.lwt.2017.01.069 . hal-01517226

\author{
HAL Id: hal-01517226 \\ https://hal.science/hal-01517226
}

Submitted on 26 Sep 2017

HAL is a multi-disciplinary open access archive for the deposit and dissemination of scientific research documents, whether they are published or not. The documents may come from teaching and research institutions in France or abroad, or from public or private research centers.
L'archive ouverte pluridisciplinaire HAL, est destinée au dépôt et à la diffusion de documents scientifiques de niveau recherche, publiés ou non, émanant des établissements d'enseignement et de recherche français ou étrangers, des laboratoires publics ou privés. 


\section{Accepted Manuscript}

How the structure, nutritional and sensory attributes of pasta made from legume flour is affected by the proportion of legume protein

Karima Laleg, Cécile Barron, Sylvie Cordelle, Pascal Schlich, Stéphane Walrand, Valérie Micard

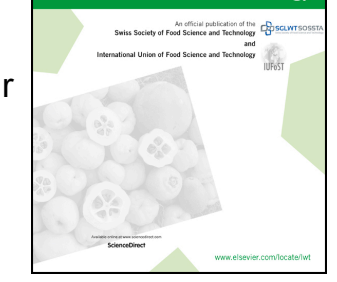

PII:

S0023-6438(17)30081-6

DOI:

10.1016/j.Iwt.2017.01.069

Reference:

YFSTL 6021

To appear in: $\quad$ LWT - Food Science and Technology

Received Date: 10 October 2016

Revised Date: 23 January 2017

Accepted Date: 25 January 2017

Please cite this article as: Laleg, K., Barron, C., Cordelle, S., Schlich, P., Walrand, S., Micard, V., How the structure, nutritional and sensory attributes of pasta made from legume flour is affected by the proportion of legume protein, LWT - Food Science and Technology (2017), doi: 10.1016/ j.Iwt.2017.01.069.

This is a PDF file of an unedited manuscript that has been accepted for publication. As a service to our customers we are providing this early version of the manuscript. The manuscript will undergo copyediting, typesetting, and review of the resulting proof before it is published in its final form. Please note that during the production process errors may be discovered which could affect the content, and all legal disclaimers that apply to the journal pertain. 
1 How the structure, nutritional and sensory attributes of pasta made from legume flour is

2

3

4

5

6

7

8 Affiliation:

10

11

12

14

17

18

Authors:

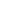
France; France.

\section{affected by the proportion of legume protein}

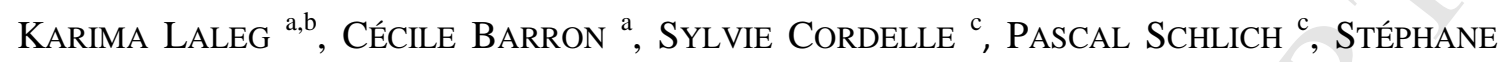
WALRAND ${ }^{\mathrm{b}}$ AND VALÉRIE MICARD ${ }^{\mathrm{a}, ~ *}$

a, UMR IATE, Cirad, Inra, Montpellier SupAgro, Université de Montpellier, F-34060 Montpellier,

${ }^{b}$, CRNH Auvergne, UNH, UMR 1019, Inra, F-63000, Clermont-Ferrand, France.

', Centre des Sciences du Goût et de l'Alimentation, CNRS, INRA, Univ. Bourgogne Franche-Comté, F-21000 Dijon, France.

\section{*Corresponding author:}

E-mail: valerie.micard@supagro.fr; JRU-IATE, 2 Place Pierre Viala, 34060-Montpellier,

Tel: +33(0)4 99612889 . 


\section{Abstract}

In this study, wheat in pasta was partially or completely replaced by faba to increase its protein quantity and improve its quality. Increasing the ratio of faba:wheat protein from 0:100 to $100: 0(\mathrm{~g} / \mathrm{g})$ in pasta enlarged its protein network at the microscopic scale and linearly diluted the covalently linked gluten network of wheat pasta by weakly linked proteins. A concomitant linear increase in the cooking loss (up to 2.6 fold), a decrease in resilience (up to 1.4 fold) and an increase of the in-vitro protein digestion (up to $25 \%$ ) were observed in pasta. The increase in drying temperature $\left(90^{\circ} \mathrm{C}\right.$ vs. $\left.55^{\circ} \mathrm{C}\right)$ promoted the covalent aggregation of proteins in all pasta, but was more efficient in legume pasta, enhancing their resilience and reducing their cooking loss, without altering the degree of protein hydrolysis. This was partly explained by the reduction in trypsin inhibitory activity in all legume pasta dried at $90^{\circ} \mathrm{C}$. Interestingly, scores for sensory attributes such as liking attributed to pasta containing $80 \%$ faba-protein were close to scores given to a commercial whole wheat pasta. Pasta made exclusively from faba dried at $55^{\circ} \mathrm{C}$ or $90^{\circ} \mathrm{C}$ tended to be liked more than their commercial gluten-free counterparts.

\section{Key words}

Protein network structure, cooking quality, in-vitro protein digestion, trypsin inhibitory activity, sensory analysis.

\section{Abbreviations}

${ }^{\circ} \mathrm{H}$ : degree of hydrolysis, DTE: dithioerythritol, F: faba, LT: low temperature, OCT: optimal cooking time, SDS: sodium dodecyl sulphate, SE-HPLC: size exclusion-high performance liquid chromatography, S-GF: gluten-free spaghetti, S-WW: whole wheat spaghetti, TDS: temporal dominance of sensation, TIA: trypsin inhibitory activity, VHT: very high temperature, W: Wheat. 


\section{Introduction}

Consumer demand for an alternative to meat proteins in the diet has been increasing in recent decades. The potential of legumes such as faba to partly replace meat intake in the human diet was reviewed by Multari, Stewart, and Russell (2015). In addition, the association of wheat and legumes in the same food helps benefit from the nutritional composition of both crops, notably their complementary essential amino acid profile (Duranti, 2006). Among several traditional wheat products, pasta is an appropriate base for this association because of its palatability, low cost and wide consumption. Legume-wheat mixed pasta with $50 \%$ of faba protein has been demonstrated to have a better essential amino acid profile than classical wheat-gluten or wheat-egg enriched pasta at identical protein content (Laleg, Barron, SanteLhoutellier, Walrand \& Micard, 2016a) with a conserved low glycemic index (Greffeuille et al., 2015). However, the total amount of essential amino acids required by the body has not yet been reached in pasta (Laleg et al., 2016a) because of technological problems that arose when more than $\sim 50 \%$ legume protein was included in the pasta (Petitot, Boyer, Minier \& Micard, 2010b; Wood, 2009). Two recent studies demonstrated that it is now possible to overcome the $50 \%$ threshold in legume protein in pasta and that it is even possible to produce pasta with legume as the only source of proteins (Laleg, Cassan, Abecassis \& Micard, 2016b;

Rosa-Sibakov et al., 2016). These completely gluten-free legume pasta could be of interest for celiac patients, or for people who wish to reduce or eliminate gluten from their diet.

However, including legume protein in pasta can also have unexpected nutritional and sensory effects. Legumes contain some protease inhibitors such as trypsin inhibitors, which can alter the digestibility of proteins (Duranti, 2006) but could be partially or totally inactivated by thermal treatment of legume pasta (Laleg, Cassan, Barron, Prabhasankar \& Micard, 2016c; Zhao, Manthey, Chang, Hou \& Yuan, 2005). In addition, it has been reported that beyond $28 \%$ of gluten protein substitution with legume protein, cooking properties and sensory 
acceptance of pasta are reduced (RayasDuarte, Mock \& Satterlee, 1996). This was attributed to the dilution or the absence of the gluten network responsible for the pleasant organoleptic and cooking quality of pasta. The use of high temperature to dry pasta has been shown to prevent the alteration of cooking, textural and organoleptic properties of classical and low legume protein $(<50 \%$ of total protein) enriched pasta by promoting covalent links between proteins (Laleg et al., 2016a). However the effect of drying temperature on pasta with higher level of legume protein substitution has not yet been studied.

The aim of this work was to study the impact of the percentage ( $0 \%$ to $100 \%$ ) of enrichment using legume protein (faba) in pasta and the impact of drying temperature (low temperature, LT, vs. very high temperature, VHT) on pasta structure and its resulting textural and cooking properties. The effects of changes in pasta formulation and/or processing on trypsin inhibitory activity and on its protein network structure and resulting in-vitro digestibility were analyzed.

Pasta with the best textural, cooking and/or nutritional qualities was subjected to consumer acceptance analyses and compared to a commercial gluten-free and a whole wheat counterpart for the first time using the Temporal Dominance of Sensations test. 


\section{Material and methods}

Wheat semolina (W) and faba flour (F) were supplied by Panzani (Marseille, France) and GEMEF industries (Aix-en-Provence, France), respectively. W and F contained, on a dry basis, 13.1 and $24.0 \mathrm{~g} / 100 \mathrm{~g}$ of proteins, 77.8 and $57.6 \mathrm{~g} / 100 \mathrm{~g}$ of starch, and 2.4 and 11.7 $\mathrm{g} / 100 \mathrm{~g}$ of fibers, respectively. The particle size distribution (D50) of W-semolina and F-flour was 252 and $25 \mu \mathrm{m}$, respectively. Whole wheat spaghetti (S-WW; Celnat, Saint-GermainLaprade, France) and gluten-free spaghetti (S-GF; Schär, Burgstall, Italy) made from maize, millet and rice were purchased from a local French market and used to evaluate the sensory attributes of our pasta.

\section{Pasta production}

Pasta containing 0 (F0), $50 \mathrm{~g}$ (F50), $80 \mathrm{~g}$ (F80) and $100 \mathrm{~g}$ (F100) of faba protein per $100 \mathrm{~g}$ of total protein were produced using a mixture of $\mathrm{W}$-semolina and F-flour at W:F (g/g) ratios of 100:0, 65:35, 30:70 and 0:100, respectively. Pasta formulation and composition are detailed in table 1. F0 and F50 pasta were processed into spaghetti as described by (Petitot et al., 2010b). F80 and F100 pasta were produced according to the WO2016097328A1 patent (Laleg et al., 2016b). F0, F50, F80 and F100 were hydrated to 47, 45, 43 and $42 \mathrm{~g} / 100 \mathrm{~g}$ (db) respectively, mixed for 20 minutes and extruded using a continuous pilot-scale pasta extruder (Bassano, Lyon, France). All the pasta were dried at low temperature $55^{\circ} \mathrm{C}(\mathrm{LT})$ or at $90^{\circ} \mathrm{C}(\mathrm{VHT})$ in a pilot-scale drier (AFREM, Lyon, France). The diameter of the dried pasta was $1.56 \pm 0.03$ $\mathrm{mm}$ for $\mathrm{F} 0$ and $\mathrm{F} 50,1.51 \pm 0.01 \mathrm{~mm}$ for $\mathrm{F} 80$ and $1.47 \pm 0.03 \mathrm{~mm}$ for $\mathrm{F} 100$ pasta. The total protein content of the dry pasta was determined in duplicate using the Kjeldahl procedure (NF V 03-050, 1970) with a conversion factor of 5.7 for wheat and of 6.25 for faba proteins. Lysine and cysteine amino acids were determined in duplicate on dry pasta at CIRAD 
108 (Montpellier, France) according to Moore, Spackman, and Stein (1958). Pasta composition is

109 detailed in table 1.

110

111

112

113

114

115

116

117

118

119

120

121

122

123

124

125

126

127

128

129

130

131

\section{Molecular structure of the protein network of dried pasta}

The extraction procedure of pasta protein was performed according to Morel, Dehlon, Autran, Leygue and Bar-L'Helgouac'h (2000). Samples of dried pasta were ground and proteins were extracted in triplicate from the raw mixtures used for pasta production (100\% semolina, $65 \%$ semolina $+35 \%$ faba, $30 \%$ semolina $+70 \%$ faba and $100 \%$ faba) and from ground pasta. The first extraction was performed in sodium dodecyl sulphate (SDS, $0.1 \mathrm{~mol} / \mathrm{L}$ ) to disrupt the electrostatic, hydrophobic and hydrophilic interactions between proteins. After centrifugation, the pellet was subjected to a second extraction in SDS $(0.1 \mathrm{~mol} / \mathrm{L})+$ dithioerythritol (DTE, $0.02 \mathrm{~mol} / \mathrm{L}$ ), and sonicated (Vibracell 72434, Bioblock Scientific, Illkirch, France) at $50 \%$ and at a frequency of $20 \mathrm{kHz}$ for $5 \mathrm{~min}$ to disrupt disulfide linked proteins. The protein size distribution of each extract was studied by size exclusion (SE)-HPLC (Morel et al., 2000). Areas (in arbitrary units) of SDS-soluble and DTE-soluble proteins were added and the sum (i.e. total extractable proteins) was expressed as a percent of the corresponding total area calculated for W-semolina (for F0), for blends of semolina and F-flour with $50 \%$ and $80 \%$ protein from F-flour (for F50 and F80, respectively), or for F-flour (for F100). The remaining pellet made of non-extractable proteins represented proteins linked by covalent linkages that were not affected by sonication and/or DTE (e.g.: isopeptide bonds).

\section{Cooking and textural properties of pasta}

Each pasta was cooked to its own optimal cooking time (OCT) in demineralized water containing $7 \mathrm{~g} / \mathrm{L}$ of salt according to the AACC approved method (66-50), and then left to rest for $10 \mathrm{~min}$ in a covered container at $25^{\circ} \mathrm{C}$ in a saturated vapor atmosphere. Optimal cooking time was $9.6 \pm 0.2 \mathrm{~min}$ for F0-LT, $10.3 \pm 0.5 \mathrm{~min}$ for F0-VHT, $9.0 \pm 0.1 \mathrm{~min}$ for F50-LT, 9.6 
$132 \pm 0.3 \mathrm{~min}$ for F50-VHT, $9.2 \pm 0.1 \mathrm{~min}$ for F80-LT, $9.5 \pm 0.1 \mathrm{~min}$ for F80-VHT, $9.5 \pm 0.2 \mathrm{~min}$

133 for F100-LT and $9.7 \pm 0.1$ min for F100-VHT.

134 Cooking losses were determined in triplicates according to the following equation:

$$
\text { Cooking loss }(\%, d b)=\frac{\text { cooked pasta }(\mathrm{g}, \mathrm{db})-\operatorname{dry} \text { pasta }(\mathrm{g}, \mathrm{db})}{\operatorname{dry} \text { pasta }(\mathrm{g}, \mathrm{db})}
$$

135 A TA-XTplus (Stable Micro Systems, Scarsdale, USA) texture profile analyzer was used to 136 evaluate the resilience of the pasta. A single strand $(2 \mathrm{~cm})$ of spaghetti was compressed, using 137 a cylindrical probe, at a constant rate of deformation $(1 \mathrm{~mm} / \mathrm{s})$ to $70 \%$ of the initial spaghetti 138 thickness. The probe was then retracted. The peak of the force $(\mathrm{N})$ was plotted as a function of deformation $(\mathrm{mm})$. Resilience was determined in 6 replicates as the ratio of the area under the second half of the peak to the area under the first half of the peak (Petitot et al., 2009).

\section{Microscopic structure of cooked pasta}

The microstructure of F0-LT, F100-LT and F100-VHT pasta cooked to OCT was observed using bright field light microscopy. Pasta sections $(8 \mu \mathrm{m})$ were stained for 10 min with fast green (Sigma Aldrich Co., USA) and for one minute with lugol (Fluka, Buchs, Switzerland) (Petitot, Barron, Morel \& Micard, 2010a). Bright field images were acquired using the multizoom AZ100M microscope (Nikon, Tokyo, Japan) equipped with a Nikon DSRi1 (Nikon, Tokyo, Japan) color digital camera. Observations were made with a plan fluor $5 \times$ objective and a fixed optical zoom of 8 , resulting in a total magnification of $40 \times$.

\section{Trypsin inhibitory activity (TIA) and in-vitro protein digestion of cooked pasta}

TIA was determined in triplicate according to the standardized method ISO14902 (2009) on water bath according to the method of Pasini, Simonato, Giannattasio, Peruffo and Curioni (2001) slightly modified. Samples were suspended in $4 \mathrm{~mL}$ of $0.2 \mathrm{~mol} / \mathrm{L} \mathrm{HCl}$ containing 
acid buffer (pH 6.8) containing 10.4 USP/mL of pancreatin (P7545, Sigma, St. Louis, US), was added. Digestion was stopped after 30 min of pepsin and 180 min of pancreatic attack by adding one volume of trichloroacetic acid $(1.2 \mathrm{~mol} / \mathrm{L})$. The amount of free amino groups $\left(\mathrm{NH}_{2}\right)$ in the digestion extracts (supernatant) were measured using the ninhydrin method (Prochazkova, Varum \& Ostgaard, 1999), at the beginning of digestion $\left(\mathrm{T}_{0}\right)$, during digestion $\left(\mathrm{T}_{\mathrm{x}}\right)$ and after a total hydrolysis of $\mathrm{T}_{0}\left(\mathrm{HCl} 6 \mathrm{~mol} / \mathrm{L}, 24 \mathrm{~h}\right.$ at $\left.105^{\circ} \mathrm{C}\right)\left(\mathrm{T}_{\text {total }}\right)$. The degree of protein hydrolysis $\left({ }^{\circ} \mathrm{H}\right)$ was calculated according to the equation:

$$
{ }^{\circ} \mathrm{H}(\%)=\frac{\mathrm{NH}_{2_{(\mathrm{Tx})}}-\mathrm{NH}_{2_{(T 0)}}}{\mathrm{NH}_{2_{(\text {Ttotal })}}-\mathrm{NH}_{2}(\mathrm{~T} 0)} \times 100
$$

\section{Sensory analysis of cooked pasta by Temporal Dominance of Sensations (TDS)}

Six pasta were tested (F0-LT, F80-LT, F100-LT and F100-VHT cooked to OCT and two commercial pasta: S-GF and S-WW cooked for 11 and $8 \mathrm{~min}$, respectively, as recommended by the manufacturer) by 43 consumers, 19 to 69 years old, balanced for gender and age. Of these, 21 were regular consumers of whole wheat pasta. Ten attributes (Table 2) were presented to the subjects prior to the sensory session. A dominant sensation was defined as a sensation that triggers the most attention at a specific point of time (Pineau et al., 2009).

Sensory sessions were organized in a sensory room lit with red light and equipped with separate booths. The subject received $45 \mathrm{~g}$ of each pasta, monadically presented. He placed one bite into his mouth, he focused on the dominant sensation and clicked on the corresponding button. When the dominant perception changed, the subject scored the new dominant sensation. He was free to choose the same dominant sensation several times or to not select an attribute as dominant at all. He carried on scoring dominant sensations after swallowing, until the perception ended. Afterwards, the subject scored his current liking on a linear scale labeled at the far left "I do not like it at all" and at the far right "I like it very much" (Meilgaard, Civille \& Carr, 2006). He proceeded in the same way for a second, then for a third bite of the pasta. For each pasta and each bite, TDS curves were produced (Pineau 
180

181

182

183

184

185

186

187

188

189

190

191

192

193

194

195

196

197

198

199

200

201

202

et al., 2009). Times were standardized between 0 (first score) and 1 ("I no longer perceive anything”) (Lenfant, Loret, Pineau, Hartmann \& Martin, 2009).

\section{Statistical analysis}

All data (except for sensory analysis) were subjected to analysis of variance (two-way ANOVA) using "formulation" and "drying" as factors. ANOVA was followed by the Fisher's least significant difference (LSD) test to compare means at the 5\% significance level, using Statistica 8.0 software (Tulsa OK, USA).

Concerning the sensory analysis, the confidence level was set to 5\%. For the liking scores, statistical calculations were performed using SAS system (SAS Institute Inc., Cary, NC, USA). The analyses of the TDS measurements were performed using TimeSens ${ }^{\circledR}$ software. The analysis of the liking scores was performed using the MIXED SAS® procedure, with product, bite, type of consumer and their three interactions of order 2 as fixed effects. Consumer and consumer interaction with bite and with product were the three random effects in this model in which bite was a repeated factor within product by consumer with a heterogeneous auto-regressive covariance structure. Subsequently, least square means were calculated for the significant effects in order to analyze the differences revealed. In addition, a canonical variate analysis (CVA) was computed to distinguish the products based on the dominance durations of the TDS attributes. A CVA can be considered as a principal component analysis of the average durations of the attributes by product using the inverse of the within product covariance matrix as a metric, i.e., taking panelist heterogeneity into account.

\section{Results and discussion}

\section{Structure of the pasta protein network}


203

204

205

206

207

208

209

210

211

212

213

214

215

216

217

218

219

220

221

222

223

224

225

226

Figure 1 shows the protein soluble in SDS (weakly linked), in DTE (disulfide linked) and non-extractable (covalently, other than disulfide, linked) protein in dry (LT and VHT) pasta as a function of the concentration of F-protein.

In LT-pasta, increasing F-protein from $0 \%$ to $100 \%$ linearly increased the weakly linked protein (SDS-soluble) at a rate of 0.24 (figure 1A) and linearly decreased disulfide linked (DTE-soluble) proteins at the same rate $(-0.25)$ (Figure 1B), with no creation of other covalently linked (non-extractable) proteins (Figure 1C). Laleg et al. (2016a) and Petitot et al. (2010b) also detected a decrease in DTE-soluble proteins concomitant with an increase in SDS-soluble proteins when they substituted $50 \%$ of wheat protein with faba or split pea flours. In their study, DTE-soluble proteins also reached $15 \%$ and $20 \%$ of total proteins for faba and split pea, respectively. However, here for the first time, we demonstrate the linear character of the weakening of protein network when the proportion of faba protein is increased in pasta. Only $4.5 \%$ of total proteins in F100-LT were disulfide bonded versus 30\% in F0-LT pasta. In the corresponding raw materials, (faba flour and wheat semolina), these percentages were 3\% and 15\%, respectively (result not shown). Only wheat proteins therefore appeared to have reacted through disulfide bonds under LT drying conditions. Even if the Fprotein contained $9.6 \mathrm{mg}$ cysteine/g protein (versus $17.2 \mathrm{mg} / \mathrm{g}$ in wheat protein; table 1 ), they only created minor disulfide linked proteins under LT drying. This fact and the linear character of the decrease in DTE-soluble protein suggests that faba proteins acted as a diluting agent of gluten in mixed wheat-faba pasta dried in LT conditions. The low water content (42$47 \%, \mathrm{db}$ ) required for the production of pasta, the low energy input during mixing: $\sim 8 \mathrm{~kJ} / \mathrm{kg}$ and extrusion: $70 \mathrm{~kJ} / \mathrm{kg}$ (Abecassis, Abbou, Chaurand, Morel \& Vernoux, 1994; IcardVerniere \& Feillet, 1999) and the choice of LT drying program, were probably not enough to force $\mathrm{W}-\mathrm{F}$ and F-F protein to interact covalently via disulfide bridges. 
In comparison to LT drying, whatever the F-protein content of the pasta, VHT drying led to a higher formation of disulfide and to the additional creation of other covalent linkages (e.g. isopeptide or Maillard products) at the expense of weakly linked proteins (Figure 1). This has already been reported in $100 \%$ wheat (De Zorzi, Curioni, Simonato, Giannattasio \& Pasini, 2007) and protein enriched pasta (with 35\% faba or 5\% egg white) (Laleg et al., 2016a). In the present study, a much higher proportion of covalently linked proteins was detected in F100-VHT than in F100-LT (32\% vs. 4\%, respectively), showing that a high drying temperature enables additional reactivity of F-proteins. Under VHT drying, disulfide bonded proteins were probably formed through the interaction of free sulfhydryl groups between wheat-wheat proteins, like in LT-pasta, but also in faba-faba protein or even wheat-faba proteins. In VHT-pasta, like in LT-pasta, the variations in all kinds of protein linkages (weak, disulfide and other covalent) as a function of the concentration of F-protein were linear. However, the rate of weakening of the protein network (increase in SDS-soluble proteins) with the increase in the F-protein concentration was twice as high in VHT pasta than in LTpasta.

\section{Microscopic structure}

Figure 2 shows the microscopic structure of F0-LT, F100-LT and F100-VHT cooked pasta. The central region of F0-LT presented compact starch granules (blue) with almost no clearly visible protein network (green). Whatever the drying temperature, F100 presented a more open structure, with highly swollen starch granules and a visibly thicker protein network. Starch granules were elongated in F0 and round/oval in F100, related to the respective shape of starch in wheat and faba raw materials (Petitot et al., 2010a). In the internal region of F100-VHT, the starch granules were slightly darker in color than in F100-LT, probably related to limited gelatinization (Cunin, Handschin, Walther \& Escher, 1995). The external region of F0-LT presented highly swollen and disintegrated starch granules in comparison to 
252 the pasta core, as already reported in the literature (Petitot et al., 2010a). In F100-LT, the

253 starch granules in the external region were as swollen as in the pasta core, and coalesced to

254 form a continuous phase at the surface of the pasta excluding protein mass. In F100-VHT, the

255 starch was held within a protein network, which was more uniformly dispersed around starch

256 granules than in F100-LT.

257

258

259

260

261

262

263

264

265

266

267

268

269

270

271

272

273

274

275

276

\section{Cooking and textural properties}

Pasta cooking losses and resilience are presented in figure $3 \mathrm{~A}$ and $3 \mathrm{~B}$, respectively. In LTpasta, increasing F-protein from $0 \%$ to $100 \%$ linearly increased the cooking loss, and linearly decreased the pasta resilience. Petitot et al. (2010b) also reported 7\% cooking loss and 0.53 resilience in pasta with faba accounting for $50 \%$ of its total protein. Rosa-Sibakov et al. (2016) found $11 \%$ cooking loss in pasta made exclusively from faba, slightly less than in the present study (14\%), but identical pasta resilience of 0.41 . The unique ability of gluten to form a protein network is the primary factor responsible for the reduced cooking loss and the good textural properties of wheat pasta (Matsuo, Bradley \& Irvine, 1972; Matsuo \& Irvine, 1970). The incorporation of non-gluten material, such as faba proteins, in pasta dilutes the gluten network and weakens its overall structure, as seen in SE-HPLC section, at least partially explaining the decrease in pasta resilience and the cooking loss. Torres, Frias, Granito, Guerra and Vidal-Valverde (2007) and RayasDuarte et al. (1996) also attributed the higher release of solids into the cooking water to the dilution of gluten network in a 5-30\% lupin enriched pasta. In addition, the presence in faba flour of more fibers than in wheat semolina (11.7 versus $2.4 \mathrm{~g} / 100 \mathrm{~g}$, db) may also have helped weaken the whole pasta structure when increasing amounts of faba were included in the pasta. According to Padalino et al. (2014) and Petitot et al. (2010b), the inclusion of pea fibers indeed promoted the formation of discontinuities or cracks inside the pasta strand, resulting in a low sensory elastic recovery. 
277 In comparison to LT drying, when increasing proportions of faba were included, VHT drying

278 linearly decreased the cooking loss and increased the pasta resilience in all faba enriched

279 pasta. The strengthening of pasta protein network by VHT drying (demonstrated in the SE-

280 HPLC section), which enabled improved entrapping of starch granules, could contribute to

281 this overall improvement in pasta quality as observed by Petitot et al. (2010b) in a

282 wheat/legume mixed pasta equivalent to our F50 pasta. We demonstrated that the reduction in

283 cooking loss and improvement in pasta resilience under VHT vs. LT drying were even more

284 pronounced with an increase in the concentration of F-protein in pasta due to the additional

285 reactivity of faba proteins notably through the creation of disulfide linked protein (see SE-

286 HPLC section) under VHT drying. Conversely, VHT drying did not reduce cooking loss or

287 enhance the resilience of F0 pasta. In addition, even if VHT allowed faba pasta to recover

288 higher resilience, this resilience did not go above the threshold value reached for a LT or VHT

289 dried $100 \%$ wheat pasta.

\section{Trypsin inhibitory activity and in-vitro protein digestibility}

292

293

294

295

296

297

298

299

300

301

The initial TIA measured in the raw blends used for pasta production was $0,3.92,6.35$ and $7.84 \mathrm{mg} / \mathrm{g}(\mathrm{db})$ respectively in F0, F50, F80 and F100 (results not shown). In cooked pasta (table 3), TIA increased significantly $(\mathrm{p}<0.05)$ following the order of F-protein incorporation to reach a maximum value of $2.28 \mathrm{mg} / \mathrm{g}$ of cooked pasta in F100. Therefore, up to the cooking step, pasta processing decreased TIA dramatically (up to 6.4 fold), as already reported in the literature (Zhao et al., 2005). The decrease in TIA was more pronounced in F50 and F80 (both 84\%) than in F100 (71\%). Trypsin inhibitors are proteins with a compact structure stabilized through disulfide bonds (Mueller \& Weder, 1989). The lower free sulfhydryl in gluten-free F100 pasta probably reduced its ability to initiate unfolding of the trypsin inhibitor by interaction with its disulfide bonds during processing (Friedman, Grosjean \& Zahnley, 1982). 
302 Eighteen, 20 and $3 \mathrm{mg}$ of TIA per gram of raw black-gram, lentil and faba grains

303 (respectively) are reported in the literature (Makkar, Becker, Abel \& Pawelzik, 1997;

304 Vasagam \& Rajkumar, 2011), which are all higher than those obtained for our cooked pasta.

305 The use of VHT drying had less effect $($ F-value $=12)$ but nevertheless had a significant effect

306 on TIA than the concentration of F-protein $($ F-value $=168)$. VHT drying decreased TIA

307 slightly but significantly $(\mathrm{p}=0.005)$ in the pasta. The activation of sulfhydryl-disulfide

308 interchanges under VHT drying probably modified the structure of the trypsin inhibitor. No

309 effect of the interaction between drying temperature and the pasta formulation was observed 310 on TIA.

311 The degree of protein hydrolysis $\left({ }^{\circ} \mathrm{H}\right)$ of cooked pasta is presented in table 3. Increasing F-

312 protein in pasta significantly increased $(\mathrm{p}<0.05)$ the ${ }^{\circ} \mathrm{H}$ of the protein in the pasta from $42 \%$ to

$31352 \%$, in the order $\mathrm{F} 0<\mathrm{F} 50<\mathrm{F} 80<\mathrm{F} 100$. This could be related to the linear weakening of the $\mathrm{F}$

314 protein network with an increase in the F-protein content in pasta observed by SE-HPLC

315 analyses. In addition to increased protein hydrolysis when $0 \%$ to $100 \%$ faba flour was

316 incorporated in the pasta, other nutritional changes were observed including an increase in

317 resistant starch (from $0.58 \pm 0.01$ to $1.16 \pm 0.01 \mathrm{~g}$ per $100 \mathrm{~g}$ of cooked pasta) and a slowdown

318 in starch digestion, with the percentage of rapidly and slowly available glucose decreasing

319 from $67.0 \pm 0.7 \%$ to $61.83 \pm 0.95 \%$ (of available carbohydrates) and increasing from $32.4 \pm$

$3200.7 \%$ to $36.4 \pm 0.95 \%$ (of available carbohydrates), respectively (Greffeuille et al., 2015;

321 Laleg et al., 2016c). The low in-vitro glycemic index and the higher protein digestibility

322 resulting from incorporation of legume flour could make legume enriched pasta highly

323 advantageous from a nutritional point of view.

324 VHT tended to increase the ${ }^{\circ} \mathrm{H}$ in all pasta containing F-protein $(\mathrm{p}=0.054)$, which was

325 surprising as it increased the percentage of covalently linked proteins in all pasta. However,

326 this could be due to the lower TIA recorded in the VHT-pasta than in LT-pasta. 


\section{Sensory evaluation}

\subsection{Liking scores}

Analysis of variance showed that the variants of pasta were perceived significantly different

in terms of liking $(\mathrm{F}=3.56, \mathrm{p}=0.04)$. Overall, the hedonic scores (table 4) were quite low,

which can be explained by the fact the pasta was presented with no butter or sauce. F0-LT

was the best liked pasta, and S-GF pasta was the least liked. The other pasta were close. F80-

LT and S-WW pasta tended to be more liked than F100-LT and F100-VHT. F80-LT was the best compromise in terms of preferences.

The analysis also underlined a significant bite effect $(\mathrm{F}=8.99, \mathrm{p}=0.0005)$. The liking scores of all pasta decreased for bite (the LSMeans for the first, the second and the third bites were 3.98, 3.85 and 3.73, respectively). However, the difference was less clear for F0-LT.

There was also a significant effect of the type of consumer $(\mathrm{F}=7.33, \mathrm{p}=0.0073)$ : on average, regular consumers of classical pasta (LSMean $=3.46)$. The product by type of consumer interaction was not significant, showing that the overall ranking of the products based on the liking scores was consistent between the two types of consumers. However, S-WW pasta was better liked by the regular consumers of whole wheat pasta (LSMean $=5.06)$ than by the regular consumers of classical pasta $($ LSMean $=3.10)$.

The TDS curves (appendix 1) show very different temporal profiles. The best liked pasta (F0LT) and the least liked one (S-GF) mainly differed in texture: the S-GF pasta had a firmer and more elastic attack and no stickiness, contrary to the F0-LT pasta. The best liked F-pasta 
firmness, contrary to F100-VHT pasta. In addition, the legume flavor was less dominant in F80-LT pasta. F100-LT had a less firm and a less elastic texture than F100-VHT, probably related to the lack in resilience measured by the instrumental method in F100-LT (textural property section).

Figure 4 shows the results of canonical variate analysis. The projections of the three bites of each variant are close, revealing very few differences in the perception of each product in progressive bites. S-GF pasta was characterized by longer dominance duration of white cereal flavor and of an elastic but firm texture. F0-LT pasta was mainly characterized by longer dominance duration of white cereal flavor and of stickiness. F100-VHT pasta was characterized by longer dominance of the legume flavor and by a firm texture. F80-LT pasta, F100-LT and S-WW pasta were close. They were longer dominated by whole wheat and legume flavors, but the variant F80-LT was perceived to be stickier longer than the two other variants.

\section{Conclusion}

In this study, the relation between the structure of protein and the cooking, nutritional and sensory properties of faba (F) enriched pasta was investigated. We demonstrated for the first time that the incorporation of F-protein linearly weakened the protein network structure of low temperature (LT) dried pasta, by diluting the gluten network without creating any additional covalent interactions between gluten and F-protein. We also demonstrated that the weakening of the protein network structure could be responsible for the increase in the invitro protein digestion. However, it altered the integrity of the pasta during cooking as well as its resilience. As a result, F-pasta were less appreciated than the traditional wheat pasta. Very high temperature (VHT) drying strengthened the protein structure of pasta, resulting in increased integrity and better resilience of all F-pasta without altering their in-vitro protein digestibility. Consequently, VHT drying can be used to improve the cooking properties of 
380 legume pasta. Interestingly, appreciation of legume pasta containing $80 \%$ or $100 \%$ F-protein

381 was similar to that of commercial counterparts made of whole wheat or gluten-free cereal.

382 The promising nutritional and sensory qualities of legume pasta thus make them an interesting

383 model, rich in good quality proteins, or gluten-free suitable for gluten intolerant people.

384 


\section{Acknowledgments}

The authors are very grateful to A.-L. Loiseau (CSG, Dijon), and G. Conéjéro (INRA, Montpellier, France) for sensory analysis and access to PHIV facilities, respectively. The authors thank J. Bonicel, T-M. Lasserre and D. Cassan (INRA Montpellier, France) for their technical assistance. This work was carried out under the VEGAGE project that received the financial support of the "Qualiment Institut Carnot".

\section{References}

Abecassis, J., Abbou, R., Chaurand, M., Morel, M.H., Vernoux, P. (1994). Influence of extrusion conditions on extrusion speed, temperature, and pressure in the extruder and on pasta quality. Cereal Chemistry, 71(3), 247-253.

Cunin, C., Handschin, S., Walther, P., Escher, F. (1995). Structural-changes of starch during cooking of durum-wheat pasta. Lebensmittel-Wissenschaft und-Technologie-Food Science and Technology, 28(3), 323-328.

De Zorzi, M., Curioni, A., Simonato, B., Giannattasio, M., Pasini, G. (2007). Effect of pasta drying temperature on gastrointestinal digestibility and allergenicity of durum wheat proteins. Food Chemistry, 104(1), 353-363.

Duranti, M. (2006). Grain legume proteins and nutraceutical properties. Fitoterapia, 77(2), 67-82.

Friedman, M., Grosjean, O.K.K., Zahnley, J.C. (1982). Inactivation of soya bean trypsin-inhibitors by thiols. Journal of the Science of Food and Agriculture, 33(2), 165-172.

Greffeuille, V., Marsset-Baglieri, A., Molinari, N., Cassan, D., Sutra, T., Avignon, A., Micard, V. (2015). Enrichment of pasta with faba bean does not impact glycemic or insulin response but can enhance satiety feeling and digestive comfort when dried at very high temperature. Food \& Function, 6(9), 2996-3005.

Icard-Verniere, C., Feillet, P. (1999). Effects of mixing conditions on pasta dough development and biochemical changes. Cereal Chemistry, 76(4), 558-565.

Laleg, K., Barron, C., Sante-Lhoutellier, V., Walrand, S., Micard, V. (2016a). Protein enriched pasta: structure and digestibility of its protein network. Food \& Function, 7(2), 1196-1207.

Laleg, K., Cassan, D., Abecassis, J., Micard, V. 2016b. Procédé de fabrication de pâte destinée a l'alimentation humaine et/ou animale comprenant au moins 35\% de legumineuse. Institut national de la recherche agronomique (INRA) - centre international d'etudes superieures en sciences agronomiques (SupAgro). France. WO2016097328 A1. 23 juin 2016., Google Patents.

Laleg, K., Cassan, D., Barron, C., Prabhasankar, P., Micard, V. (2016c). Structural, Culinary, Nutritional and Anti-Nutritional Properties of High Protein, Gluten Free, 100\% Legume Pasta. PLoS ONE 11(9).

Lenfant, F., Loret, C., Pineau, N., Hartmann, C., Martin, N. (2009). Perception of oral food breakdown. The concept of sensory trajectory. Appetite, 52(3), 659-667.

Makkar, H.P.S., Becker, K., Abel, H., Pawelzik, E. (1997). Nutrient contents, rumen protein degradability and antinutritional factors in some colour- and white-flowering cultivars of Vicia faba beans. Journal of the Science of Food and Agriculture, 75(4), 511-520.

Matsuo, R.R., Bradley, J.W., Irvine, G.N. (1972). Effect of protein content on the cooking quality of spaghetti. Cereal Chemistry, 49(6), 707-711.

Matsuo, R.R., Irvine, G.N. (1970). Effect of gluten on cooking quality of spaghetti. Cereal Chemistry, 47(2), 173-180. 
Meilgaard, M.C., Civille, G.V., Carr, B.T. (2006). Sensory evaluation techniques (3rd ed.). Boca Raton: CRC Press LLC.

Moore, S., Spackman, D.H., Stein, W.H. (1958). Chromatography of amino acids on sulfonated polystyrene resins an improved system. Analylical Chemistry, 30(7).

Morel, M.H., Dehlon, P., Autran, J.C., Leygue, J.P., Bar-L'Helgouac'h, C. (2000). Effects of temperature, sonication time, and power settings on size distribution and extractability of total wheat flour proteins as determined by size-exclusion high-performance liquid chromatography. Cereal Chemistry, 77(5), 685-691.

Mueller, R., Weder, J.K.P. (1989). Isolation and characterization of 2 trypsin-chymotrypsin inhibitors from lentil seeds (Lens culinaris Medik). Journal of Food Biochemistry, 13(1), 39-63.

Multari, S., Stewart, D., Russell, W.R. (2015). Potential of fava bean as future protein supply to partially replace meat intake in the human diet. Comprehensive Reviews in Food Science and Food Safety, 14(5), 511-522.

Padalino, L., Mastromatteo, M., Lecce, L., Spinelli, S., Conto, F., Del Nobile, M.A. (2014). Chemical composition, sensory and cooking quality evaluation of durum wheat spaghetti enriched with pea flour. International Journal of Food Science \& Technology, 49(6), 1544-1556.

Pasini, G., Simonato, B., Giannattasio, M., Peruffo, A.D.B., Curioni, A. (2001). Modifications of wheat flour proteins during in vitro digestion of bread dough, crumb, and crust: An electrophoretic and immunological study. Journal of Agricultural and Food Chemistry, 49(5), 2254-2261.

Petitot, M., Barron, C., Morel, M.-H., Micard, V. (2010a). Impact of legume flour addition on pasta structure: consequences on its in vitro starch digestibility. Food Biophysics, 5(4), 284-299.

Petitot, M., Boyer, L., Minier, C., Micard, V. (2010b). Fortification of pasta with split pea and faba bean flours: Pasta processing and quality evaluation. Food Research International, 43(2), 634641.

Petitot, M., Brossard, C., Barron, C., Larre, C., Morel, M.H., Micard, V. (2009). Modification of pasta structure induced by high drying temperatures. Effects on the in vitro digestibility of protein and starch fractions and the potential allergenicity of protein hydrolysates. Food Chemistry., 116(2), 401-412.

Pineau, N., Schlich, P., Cordelle, S., Mathonniere, C., Issanchou, S., Imbert, A., . . Kosterf, E. (2009). Temporal Dominance of Sensations: Construction of the TDS curves and comparison with time-intensity. Food Quality and Preference, 20(6), 450-455.

Prochazkova, S., Varum, K.M., Ostgaard, K. (1999). Quantitative determination of chitosans by ninhydrin. Carbohydrate Polymers, 38(2), 115-122.

RayasDuarte, P., Mock, C.M., Satterlee, L.D. (1996). Quality of spaghetti containing buckwheat, amaranth, and lupin flours. Cereal Chemistry, 73(3), 381-387.

Rosa-Sibakov, N., Heinio, R.-L., Cassan, D., Holopainen-Mantila, U., Micard, V., Lantto, R., Sozer, N. (2016). Effect of bioprocessing and fractionation on the structural, textural and sensory properties of gluten-free faba bean pasta. LWT - Food Science and Technology, 67, 27-36.

Torres, A., Frias, J., Granito, M., Guerra, M., Vidal-Valverde, C. (2007). Chemical, biological and sensory evaluation of pasta products supplemented with alpha-galactoside-free lupin flours. Journal of the Science of Food and Agriculture, 87(1), 74-81.

Vasagam, K.P.K., Rajkumar, M. (2011). Beneficial influences of germination and subsequent autoclaving of grain legumes on proximate composition, antinutritional factors and apparent digestibility in black tiger shrimp, Penaeus monodon Fabricius. Aquaculture Nutrition, 17(2), E188-E195.

Wood, J.A. (2009). Texture, processing and organoleptic properties of chickpea-fortified spaghetti with insights to the underlying mechanisms of traditional durum pasta quality. Journal of Cereal Science, 49(1), 128-133.

Zhao, Y.H., Manthey, F.A., Chang, S.K.C., Hou, H.J., Yuan, S.H. (2005). Quality characteristics of spaghetti as affected by green and yellow pea, lentil, and chickpea flours. Journal of Food Science, 70(6), S371-S376. 
481

482

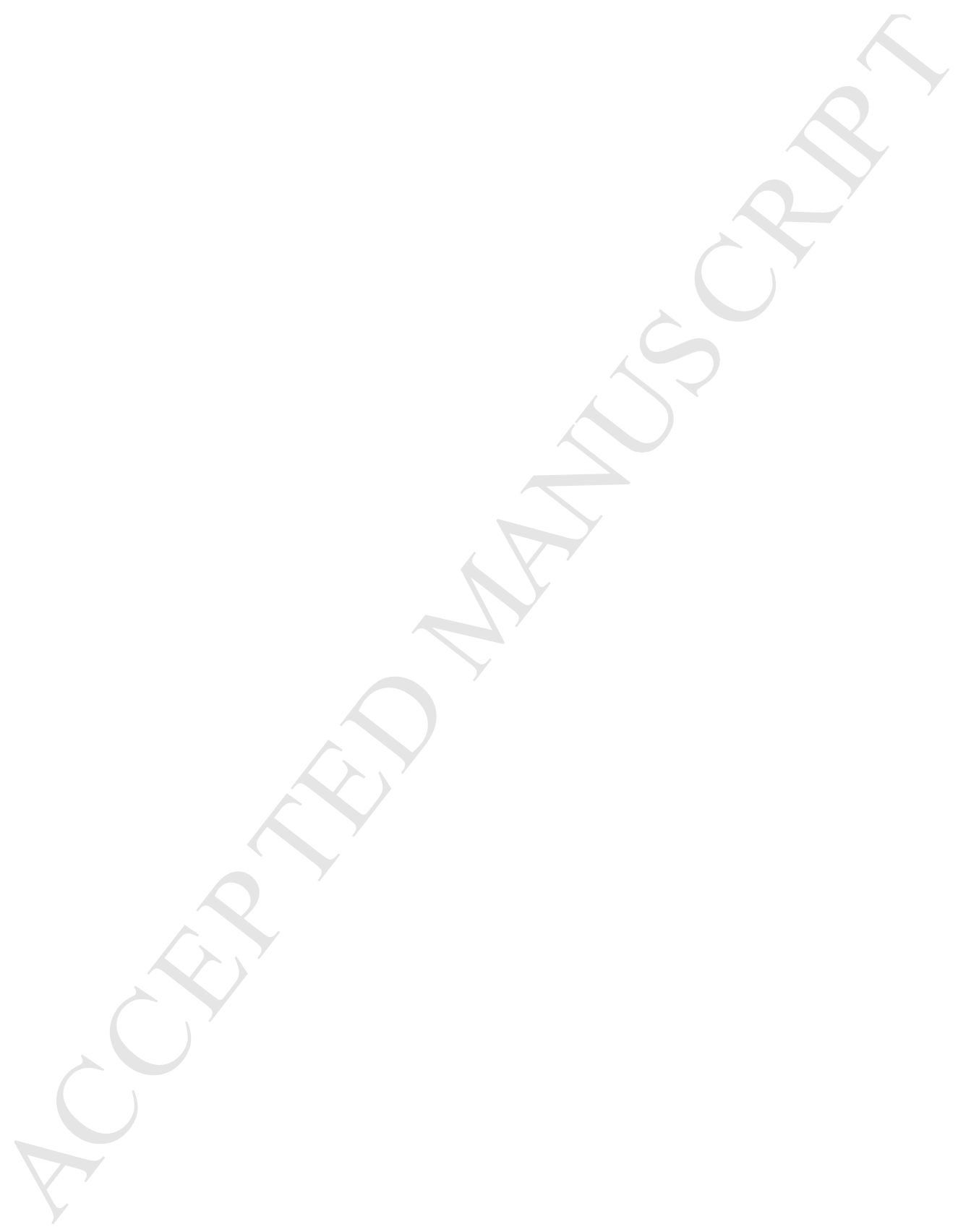

Comment citer ce document:

Laleg, K., Barron, C., Cordelle, S., Schlich, P., Walrand, S., Micard, V. (Auteur de

correspondance) (2017). How the structure, nutritional and sensory attributes of pasta made from legume

flour is affected by the proportion of legume protein. LWT - Food Science and Technology, 79, 
Figure 1. Changes in sodium dodecyl sulphate (SDS, A), dithioerythritol (DTE, B) soluble proteins and insoluble protein (non-extractable, C) from pasta dried at low temperature (LT) or very high temperature (VHT), as a function of the percentage of faba bean (F) protein in the pasta.

Experimental data (means of three replicates): $\diamond$ LT; $\diamond$ VHT. Formulation: significant effect $(\mathrm{p}<0.05)$ on SDS and DTE-soluble protein; Drying: significant effect $(\mathrm{p}<0.05)$ on SDS, DTE-soluble and non-extractable protein. Best fit (y): --- LT; -VHT.

- SDS-soluble protein: $\mathrm{y}_{\mathrm{LT}}=0.24 \mathrm{x}+70.39 ; \mathrm{R}^{2}=1.00, \mathrm{y}_{\mathrm{VHT}}=0.42 \mathrm{x}+22.40 ; \mathrm{R}^{2}=1.00$.

- DTE-soluble protein : $\mathrm{y}_{\mathrm{LT}}=-0.25 \mathrm{x}+30.69 ; \mathrm{R}^{2}=0.99, \mathrm{y}_{\mathrm{VHT}}=-0.36 \mathrm{x}+69.12 ; \mathrm{R}^{2}=0.99$.

- Non-extractable protein : $\mathrm{y}_{\mathrm{VHT}}=-0.06 \mathrm{x}+8.61 ; \mathrm{R}^{2}=0.98$.

496

497

498

499

500

501

502

503

504

505

506

507

508

509

510
Figure 2. Light microscopy of cooked pasta containing $100 \%$ wheat protein and dried at low temperature (Top panels F0-LT); and pasta containing 100\% faba protein and dried at low temperature (Middle panels F100-LT) and very high temperature (bottom panels F100-VHT).

Figure 3. Changes in cooking loss (A) and resilience (B) of cooked pasta dried at low temperature (LT) or very high temperature (VHT) as a function of the percentage of faba bean (F) protein in pasta. $\diamond$ LT; $\checkmark$ VHT. Cooking losses are means of three replicates. Resilience is the mean of six replicates. Formulation and drying had a significant effect $(\mathrm{p}<0.05)$ on cooking loss and resilience. Best fit (y): --- LT; - VHT.

- Cooking loss: $\mathrm{y}_{\mathrm{LT}}=0.08 \mathrm{x}+5.55 ; \mathrm{R}^{2}=0.94, \mathrm{y}_{\mathrm{VHT}}=0.04 \mathrm{x}+5.29 ; \mathrm{R}^{2}=0.95$.

- Resilience: $\mathrm{y}_{\mathrm{LT}}=-0.002 \mathrm{x}+0.59 ; \mathrm{R}^{2}=0.94$.

Figure 4. Canonical variate analysis $(83.1 \%)$ based on the dominance durations of the TDS attributes. 


\section{Tables}

Table 1. Formulation of pasta and protein composition of pasta made from different mixtures of wheat (W) semolina and F (faba) flour; and the lysine and cysteine contents of pasta dried at low temperature (LT) and very high temperature (VHT).

\begin{tabular}{|c|c|c|c|c|}
\hline Amounts of raw materials $(\mathrm{g} / 100 \mathrm{~g}, \mathrm{db})$ & F0 & F50 & F80 & F100 \\
\hline W-semolina & 100 & 65 & 30 & 0 \\
\hline F-flour & 0 & 35 & 70 & 100 \\
\hline \multicolumn{5}{|l|}{ Protein composition } \\
\hline Total protein content $(\mathrm{g} / 100 \mathrm{~g} \text { of pasta, } \mathrm{db})^{\mathrm{a}}$ & $13.1 \pm 0.0$ & $16.9 \pm 0.1$ & $20.7 \pm 0.0$ & $24.0 \pm 0.1$ \\
\hline W-protein $(\mathrm{g} / 100 \mathrm{~g} \text { of pasta, } \mathrm{db})^{\mathrm{b}}$ & 13.1 & 8.5 & 3.9 & 0.0 \\
\hline F-protein $(\mathrm{g} / 100 \mathrm{~g} \text { of pasta, } \mathrm{db})^{\mathrm{b}}$ & 0.0 & 8.4 & 16.8 & 24.0 \\
\hline W/F-protein ratio $(\mathrm{g} / \mathrm{g})^{\mathrm{b}}$ & $100 / 0$ & $50 / 50$ & $20 / 80$ & $0 / 100$ \\
\hline \multicolumn{5}{|l|}{ 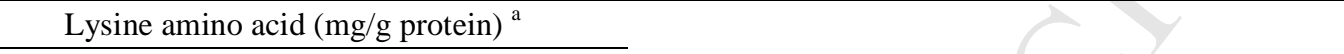 } \\
\hline LT-dried pasta & $20.5 \pm 0.6$ & $38.6 \pm 0.2$ & $55.0 \pm 0.5$ & $65.1 \pm 0.3$ \\
\hline VHT-dried pasta & $20.3 \pm 1.8$ & $33.4 \pm 1.1$ & $52.4 \pm 3.0$ & $60.3 \pm 1.3$ \\
\hline \multicolumn{5}{|l|}{ Cysteine amino acid (mg/g protein $)^{a}$} \\
\hline LT-dried pasta & $17.2 \pm 0.1$ & $14.8 \pm 0.6$ & $10.4 \pm 0.5$ & $9.6 \pm 0.7$ \\
\hline VHT-dried pasta & $17.4 \pm 0.2$ & $15.4 \pm 0.3$ & $10.4 \pm 0.4$ & $8.8 \pm 0.3$ \\
\hline
\end{tabular}

\footnotetext{
${ }^{\mathrm{a}}$ Analyses were performed in duplicate.

${ }^{b}$ Results obtained by calculation according to the ratio of raw materials and their protein composition.
} 
Table 2. Temporal dominance of sensation (TDS) list of attributes with their definitions and/or references

\begin{tabular}{llll}
\hline Attribute & Type & Definition & References \\
\hline Firm & Texture & Firmness, chewing resistance & $/$ \\
Floury & Texture & Like texture of flour in mouth & $/$ \\
Sticky, pasty & Texture & Sticks to teeth and palate & $/$ \\
Elastic & Texture & Deforms without breaking & $/$ \\
Rough & Texture & Irregularities perceived at the surface of the & $/$ \\
Salty & Taste & Salty taste & $/$ \\
Legume & Flavor & Flavor of lentils, beans, chickpeas, etc. & Cooked lentils, cooked beans, \\
White cereal & Flavor & Flavor of white flour, refined wheat & etc. \\
Whole cereal & Flavor & Flavor of whole-wheat flour, buckwheat & White flour \\
Grilled & Flavor & Grilled and toasty flavor & buckwheat flour, cooked \\
\hline
\end{tabular}


Table 3. Two-way analysis of variance (ANOVA) of trypsin inhibitory activity (TIA, mg/g db) and the degree of in-vitro protein hydrolysis $\left({ }^{\circ} \mathrm{H} ; \%\right.$ of total protein) in cooked pasta containing different concentration of faba bean protein. F0, F50, F80 and F100 present pasta in which 0, 50, 80 and $100 \%$ (respectively) of total proteins originated from faba bean.

\begin{tabular}{|c|c|c|c|c|c|c|c|c|c|c|}
\hline & \multirow{2}{*}{\multicolumn{3}{|c|}{ Analysis of variance ${ }^{a}$}} & \multicolumn{6}{|c|}{$\begin{array}{c}\text { Comparison of means-LSD test at the 5\% } \\
\text { significance }^{\text {b }}\end{array}$} & \multirow{3}{*}{$\begin{array}{l}\text { Pooled standard } \\
\text { deviation }\end{array}$} \\
\hline & & & & \multicolumn{4}{|c|}{$\begin{array}{c}\text { Effect of F-protein } \\
\text { concentration }\end{array}$} & \multicolumn{2}{|c|}{$\begin{array}{c}\text { Effect of } \\
\text { drying }\end{array}$} & \\
\hline & Effects & $\begin{array}{c}\mathrm{p}- \\
\text { value }\end{array}$ & $\begin{array}{c}\text { F- } \\
\text { value }\end{array}$ & F0 & F50 & F80 & P100 & $\mathrm{LT}$ & VHT & \\
\hline \multirow{3}{*}{$\begin{array}{l}\text { TIA } \\
(n=3)\end{array}$} & $\begin{array}{l}\text { A : F-protein } \\
\text { concentration }\end{array}$ & 0.000 & 168 & ND & $0.61^{\mathrm{a}}$ & $1.03^{\mathrm{b}}$ & $2.28^{\mathrm{c}}$ & & & 0.21 \\
\hline & B : Drying & 0.005 & 12 & & & & & $1.44^{\mathrm{a}}$ & & 0.77 \\
\hline & Interaction : $\mathrm{A} \times \mathrm{B}$ & 0.480 & 0.8 & & & & & & & \\
\hline \multirow{3}{*}{$\begin{array}{c}{ }^{\circ} \mathrm{H} \\
(\mathrm{n}=4)\end{array}$} & $\begin{array}{l}\text { A : F-protein } \\
\text { concentration }\end{array}$ & 0.000 & 75 & $42^{\mathrm{a}}$ & $46^{\mathrm{b}}$ & $48^{\mathrm{c}}$ & $52^{\mathrm{d}}$ & & & 2 \\
\hline & B : Drying & 0.054 & 4 & & & & & $46^{\mathrm{a}}$ & $47^{\mathrm{a}}$ & 4 \\
\hline & Interaction : $\mathrm{A} \times \mathrm{B}$ & 0.416 & 1 & & & & & & & \\
\hline
\end{tabular}

${ }^{a}$ Two-way ANOVA was performed using F-protein concentration and pasta drying temperature as factors

${ }^{\mathrm{b}}$ Values in the same row with the same lower case letters are not significantly different $(\mathrm{P}>0.05)$. For each effect analyzed, the mean value for all conditions tested for the other effect is given.

ND: not detected by the method used. 
Table 4. Average liking scores for the different variants of pasta (LSMeans).

\begin{tabular}{cc}
\hline Pasta & Average liking score $(\mathrm{n}=43)$ \\
\hline F0-LT & $4.88^{\mathrm{a}}$ \\
S-WW & $4.08^{\mathrm{ab}}$ \\
S-GF & $2.81^{\mathrm{c}}$ \\
F80-LT & $3.95^{\mathrm{ab}}$ \\
F100-LT & $3.72^{\mathrm{bc}}$ \\
F100-VHT & $3.67^{\mathrm{bc}}$
\end{tabular}

Variants with the same letter are not significantly different. Pooled standard deviation: $2.33 \quad(95 \%$ confidence intervals). 


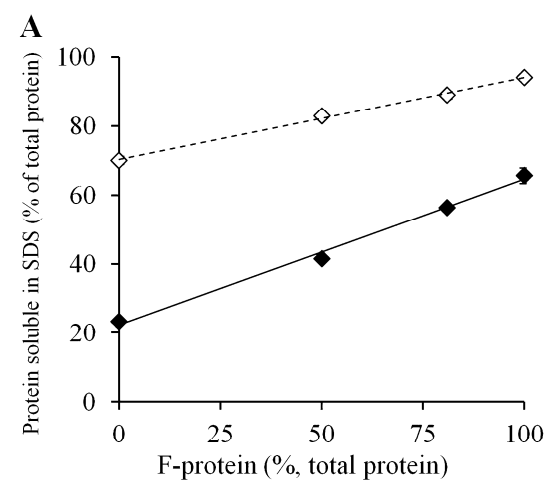

B

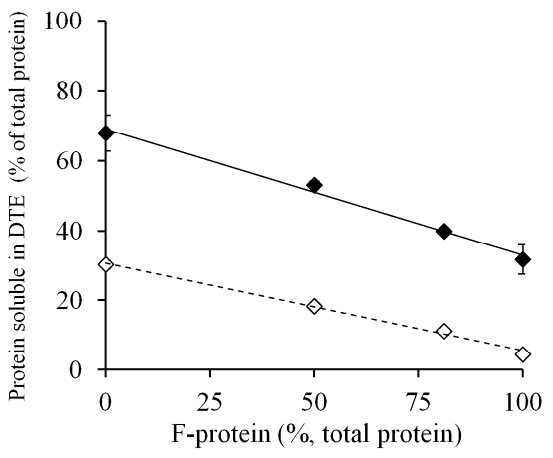

C
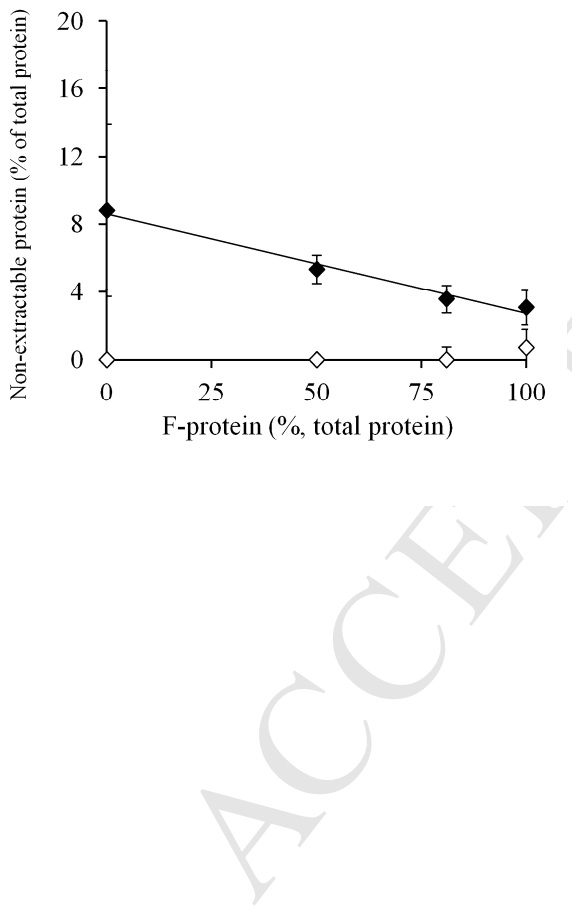

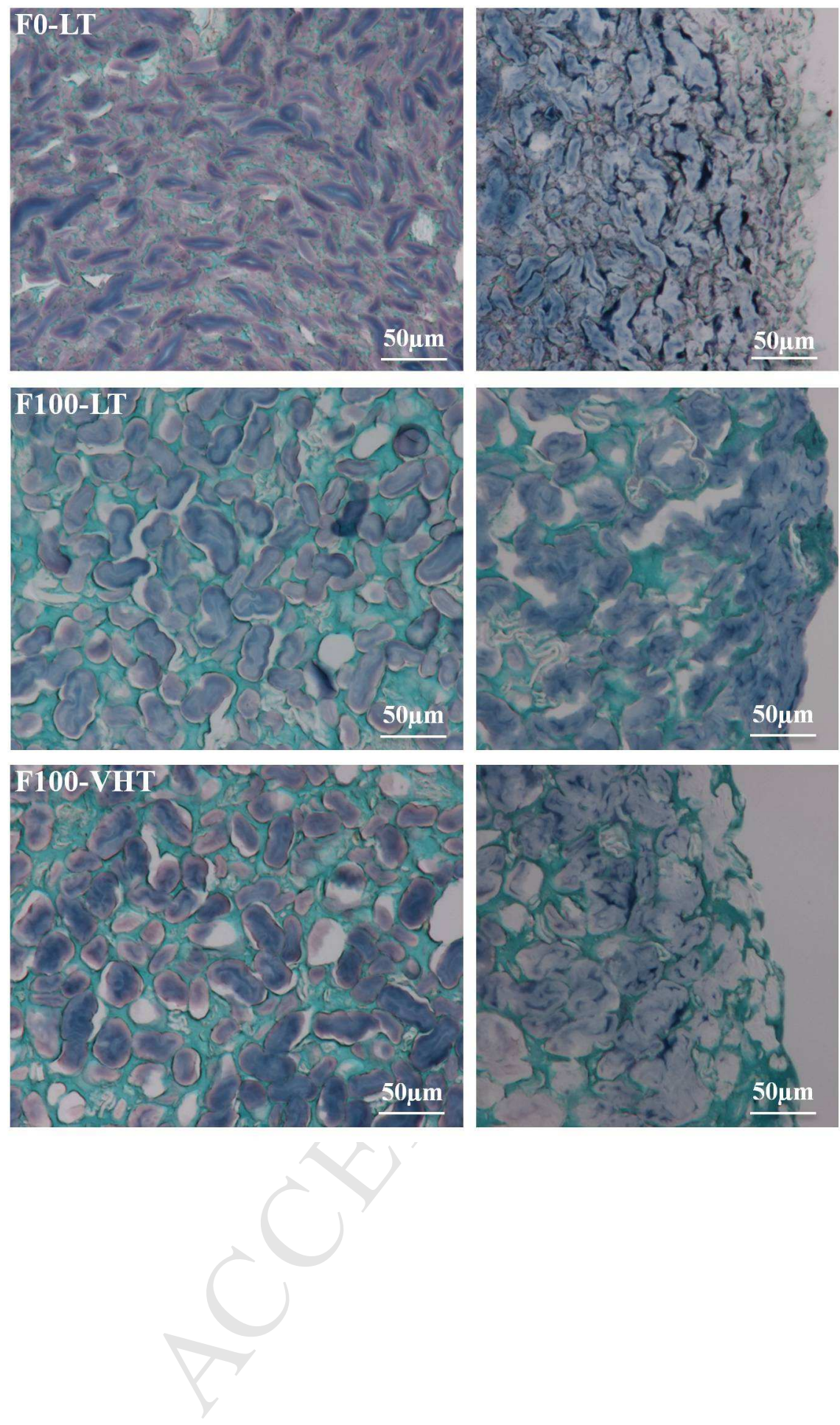
A

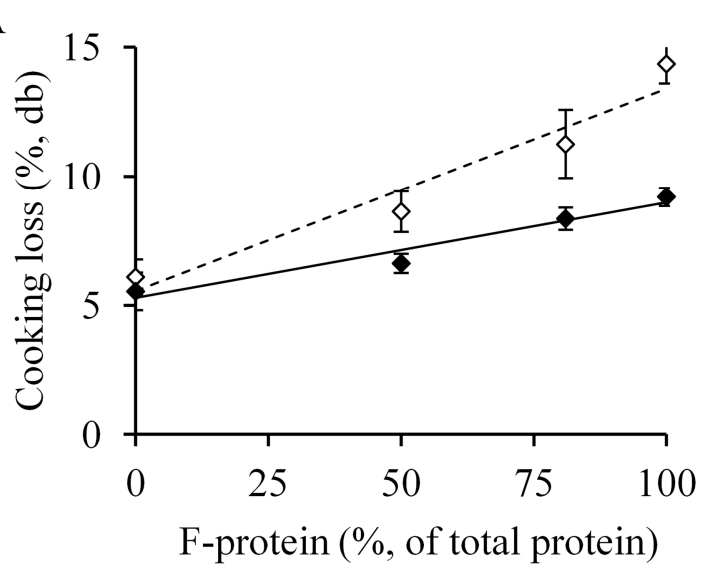

$\mathrm{B}$

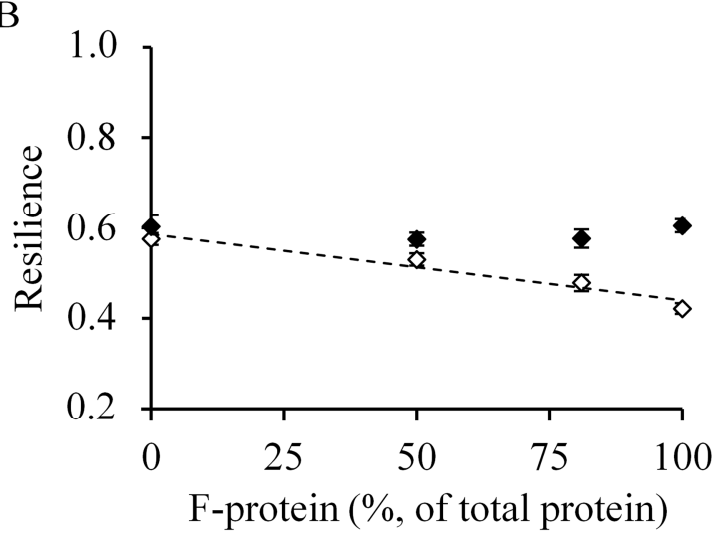




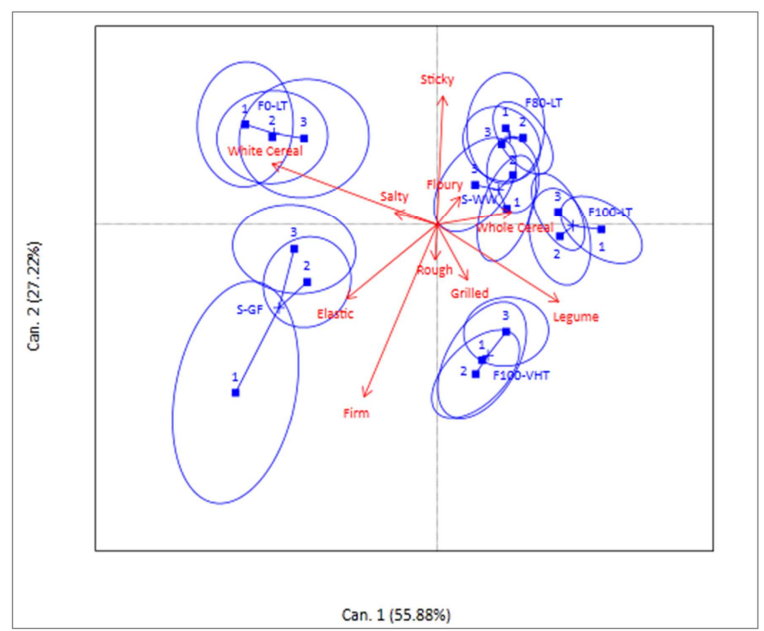


Highlights

- Pasta enrichment in faba linearly weakens its protein network

- Increasing faba protein concentration in pasta enhances its in-vitro digestion

- High-temperature drying strengthens legume pasta structure

- Increasing drying temperature does not alter legume pasta protein digestibility

- Good quality protein or gluten-free legume pasta were appreciated by consumers 